\title{
EARLY ADOLESCENT BEHAVIOR ON MEDIA TOWARD IDOL FIGURE (PARASOCIAL STUDY ON PRELIMINARY YOUTH AS AN EFFECT OF NEW MEDIA)
}

YUGIH SETYANTO, SEPTIA WINDUWATI \& LUSIA SAVITRI SETYO UTAMI

Lecturer, Faculty of Communication, Tarumanagara University, West Jakarta, Indonesia

\section{ABSTRACT}

Adolescence period is the transition period from children to adulthood. Teenagers tend gather with a group of friends who have the same interests and tends to listen their friends more. Supported by globalization and advancement in information technology, media usage rate among teenagers is increasing. Through such conditions, many teens now rely on the media as a tool to get rid of boredom and loneliness. In the parasocial interaction between fans and their idol, the role of media is very important, considering the fans are not able to meet directly with their idols. The problems of this research departs from various types of fans's media behavior, especially teenagers towards their idol, this also leads to the parasocial behavior of the fans towards their idol figure. Issues that will be examined here is to find out how the behavior of early adolescents on media towards their idol, and their contribution to the parasocial behavior interaction with their idol.

This study used qualitative approach and descriptive methods as data collection through interviews with several informants who are in early adolescence (female) and fans of singer group One Direction whose age are around 11 to 15 years. The results of this research are all the informant in this study is a spectator or active audience that watch and always updates the latest news about their idol and that media consumption behavior led to parasocial interaction. Parasocial interaction behavior that is found on the informants in this study are: pseudofriendship, social interaction (making friends), empathy for the performers (sense of companionship), the competence of the performers, the reality of the relationship, the Code of Conduct as well as pathological audience.

KEYWORDS: Media, Early Teens, Idol, Fan \& Parasocial

Received: Feb 08, 2017; Accepted: Mar 28, 2017; Published: Apr 13, 2017; Paper Id.: IJCMSJUN20171

\section{INTRODUCTION}

\section{Background}

In the parasocial interaction between fan and their idol, role of the media is important, because the fans are not able to meet directly with their idols. It can be seen from how people began to idolize an artist they see on television, hear on the radio or know and access through new media such as Youtube or on the Internet. The fans then will automatically try to meet their 'needs' of the idol by following consistently the idol's every appearance on many occasion, whether on TV, radio, film and other media.

With the continuity and high consistency of consuming things about the idol, then the fans will feel a friendship with the idol that later would affect the day-to-day behavior. They will feel that the idol is present in themselves, be a part of their lives, or even possible to make their idol as role models who each word, appearance, 
speech and habit be replicated and followed.

The problems of this research departs from many types of media behavior of fans, especially teenagers towards their idol, that leads also to their parasocial behaviortowards their idol. In worshiping o their idol, a fan could even overreacting and refers to fanaticism. The nature of excessive fanatism towards idol is called as one of the behaviors in the parasocial interaction, for example, not only watching or finding out information about the idol consistently, but it could refer to the physical or psychological act, such as the desire for a picture together, kissing, pinching, biting, or hug their idol.

The study of the parasocial behavior of fans towards their idol is still quite new in Indonesia, especially to be drawn into communication area. Researchers drew this research into communication domains with the opinion of Windahl and Rosengren (in Rubin, 2002) about the relationship between audience engagement, the closeness of reality, and media dependency. They reveal that the audience could be looking for an alternative to the media as a function of personal interaction, such as an additional, complementary, or even a substitute, for a variety of reasons such as compensation, change, escape, or self made experience. They also noted that the need for interaction and identification can produce different degrees of involvement of media such as detachment, parasosial interactions, identification of solitary, or arrest. They also argue that by combining traditional media effects and the use of media, it is possible to question what effect given on the use of the mass media, or what grativication it gives, that the media might have.

From Rosengren and Windahl's opinion, it is clearly stated that one of the outputs of the use and involvement of the media on the interaction of personal behavior is parasocial interaction. Thus, through this research, researchers tried to show how the behavior of media in teenagers have effect on their parasocial behavior interaction, especially towards their idol figure, as a substitute or alternative functions on their personal interaction. Then, the study is as research in communication area becausewe see parasocial behavior of the adolescent through the behavior on using mass media, especially new media. Thus, this research is included in the study of communication even though its basedon psychology.

Based on these descriptions, the research questions are how does the meda behavior ofOne Direction early adolescent fans towards their idol and how they contribute to the behavior of media interaction by their parasocial behavior?

\section{LITERATURE REVIEW}

\section{Uses and Gratification Theory}

The main assumption in uses and gratification theory are what the audience do against media (Katz, Blumer \& Gurevitch, 1974 in West \& Turner, 2010: 397), which is as follows:

- Audience considered active and media usage is one of the aims to fulfill their needs.

- Connecting fulfillment as a special medium with their audience.

- Media competes with other media for fulfillment of needs.

- Viewers have the self-awareness on using media, interest and motivation that could illustrate the media usage.

- Media content assesment can only be done by the audience. 
Media usage activities also depends on the social context, potential for interaction and attitude. Elements such as mobility and loneliness are important. Low mobility and high loneliness tends to produce ritualized orientation and large dependence on media (Perse \& Rubin, 1990; A. M. Rubin \& Rubin, 1982a in Bryman \& Zilman, 2002 page 535).

\section{Parasocial Interaction}

\section{- Parasosial Interaction and Mass Media}

Although viewers cannot speak with the performers they saw in the mass media, the audience can form relationship with their favorite performer (Gilles, 2000). A researcher from the Netherlands, Pekka (2002: 178) identified five dimensions that describe the interaction parasosial:

- Imaginary friendship, shows that the audience see the performer as equal as themself or their friends (identification with the performer). The audience also fantasized that they can be good friend with the performer when they meet someday.

- Finding friends, the audience is ready to spend time to watch the the performance and look for programs where the the performer is present.

- Empathy to the performer, the audience feels what the performer is feeling, for example they feel harmed when their idol are harmed.

- The reality of the relationship, the audience not only think of their idol when they're looking at the program, but the audience will try to visit the performer.

- Competence of the performer are also on their performances, that also plays role in shaping the parasocial interaction.

\section{Para Social Interaction Have These Effects}

- Sense of companionship. By forming relationships and parasocial interactions, people feel a satisfaction in their social interaction needs (Hoffner, 2002; Gleich, in Giles, 2002).

- Pseudo-friendship; emergence of false feelings of friendship between the television audience with the performer (Hoffner, 2002). Koenig and Lessan (in Cole \& Leets, 1999) called it quasi-friendship. Meanwhile, Vorderer (in Giles, 2002) called it quasi-social-relationship.

- Guidelines in behavior, social behavior, and cultural values of the performer became a guide for the people to behave similarly in their daily lives. (McCourt \& Fitzpatrick, 2001; Hoffner, 2002).

- Personal Identity, individual use the performer's behavior situation in the mass media or in the real world to interpret and understand their own life (Mc Quail, et.al., in Giles, 2002).

- Pathologic Audience, viewers who form a relationship and a very strong interaction towards the performer can cause pathological symptoms because they will imitate whatever is done by performer (Giles, 2002). 


\section{Loneliness}

Loneliness, is a subjective experience, depending on the person's interpretation of the various situations. According to a survey conducted by Rubenstein and Shaver (in Widyarini, 2004), there are four common factors feelings that arise when one is in loneliness, such as despair, panic and weak, depressed, bored, impatient, and condemn yourself.

This loneliness will disappear when it found a new social network. Various reactions arise in the face of loneliness, could be either passive and active reaction. Passive reaction may include crying, sleeping, eating, drinking, using tranquilizers, constantly watching TV. While the active reaction may involved in activities such as hobby, learning, exercising, going to the cinema, shopping while having fun, cultivate social contacts, call, or visit other people.

Adolescents experience loneliness in their life both emotionally and socially, (2004). In Rottenberg and Hymel (1994: 41), Weiss reveals that adolescents often experience emotional loneliness due to changes in the viscosity and the social system in their life. Adolescence is a period of transition from childhood into adulthood, which has affected everyone in its growth. According to Mediati (2009), loneliness becomes one of the factor that rise individual behavior towards performers they saw and consume through the media.

Adolescents experience loneliness in his life both emotionally and socially, (2004). In Rottenberg and Hymel (1994: 41), Weiss reveals that adolescents often experience emotional loneliness due to changes in viscosity and social system in their self. Adolescence is a transition period from childhood into adulthood which are experienced by each person in growing time. Loneliness, in a study conducted by Mediati (2009) became one of the factors that caused individual parasosial behavior towards performers they saw and consume through media.

\section{Teens and the New Media}

The development of new media raises the number of sites, networks of friends and social networks such as YouTube, Face book and micro-blogging site Twitter. The presence of this new media in accordance with the characteristics it has, further increase the integration function and interaction of media that allows an individual make friends apart from people while identifying himself between others. The mass media, especially new media have an impact on the audience although the effect is not necessarily the same for every individual.

\section{- Internet Interactivity and Its Effect}

The biggest thing that makes user (especially teenagers) interested in media is on the content that can be accessed from the media. For some segments that look at demographic and psychographic factors, surfing the web or chatting felt more exciting than watching television and helps eliminate stress they experienced at work and personal life. (Brymant Zilman, 2002: 586). McKenna and Barg (1999), in Brymant Zilman (2002) insists on how the main functions of the Internet at home is as a medium of interpersonal communication (e-mail usage, also the use of chat rooms, bulletin boards and virtual community). Research conducted are looking at how the relationship between the individual traits and differences with the choice of the Internet as social media, focusing on social anxiety, loneliness, the rush and secure feeling on individual. (P 589)

Kraur et al (1998) found that the greater use of the Internet affected the decline in the amount of personal social relationships. Internet user are linked to the increase of loneliness. 
Early Adolescent Behavior on Media Toward Idol Figure

(Parasocial Study on Preliminary Youth as an Effect of New Media)

\section{Uses and Gratification and New Media}

Through some research that has been conducted by researchers such as John Serry et al, Leung and Wei who uses the theory of Uses and Gratification in new media or new technology, it was concluded that although the medium is different, but the theory is still able to explain how each audience relate to the use of new media. Overall, it can be said that this theory provides an important framework for the study of new media. So, the theory of Uses and Gratification is still very useful and can be applied to new media.

The research of uses and gratification in this case focuses on the motivation and consumption of audience to see what people do with media (Klapper, 1963 in Bryman and Zilman, 2002, page 529). Research Cowles (1989) found that

interactive media (eg, media and social networking on the Internet) is considered to have more personal characteristics than non-interactive media. Perse and Courtright (1993) also observed that interpersonal channels (eg, conversations and phone) deemed to have more "Social presence" and able to satisfy more the needs of the person. Armstrong and Rubin (in Bryman \& Zilman, 2002: 535) also see the Internet as a functional alternative to face-to-face communication for those who could not get it.

\section{Youth as a Fan}

In growing adolescence, 'social cognition' is the ability to understand others who encourage teenagers to establish a more intimate social relationships with peers either through friendship or romance. At this time also growing an attitude of 'comforty' or conformity, a tendency to give up or follow the opinion, opinions, values, habits, interests or desires of others (peers). This conformity attitude grew among peer group. The forms of support peer group refers to a form of social support proposed by House (in Smet, 1994) in the form of emotional support, appreciation, instrumental and information.

Adolescents as a fan, disseminate mutual information to fellow fans. There are several definitions of the fans, which are:

- Fans refers to individuals who have a sense of love in something like a health club, people, art, ideas, or trend (Evans \& Hesmondhalgh, 2005: 151).

- Jenkins (2003) describes a fan as a specific type of audience, which can be distinguished from the majority of consumers of media texts.

- Thorne and Bruner (2006) explains there are characteristics that can be found on fans and affect their behavior, which has associated internal, external, the desire to have and the desire to interact socially with other fans.

According to Fiske (2011, trans.), fan is not passive, but rather is an ideal example of an active audience because of their strong attachment between the fan with the idol, which in addition to consuming they also interpret and respond to media texts. Fans is someone who likes or very enthusiastic about something. They usually show enthusiasm by 'promoting' and provide 'attention' to the person or the bands they idolize.

Fans usually have great interest that even afford his lifestyle just to show allegiance to the subject they idolized. In addition, fan also have the desire for external involvement-they are always motivated to show their participation on matters related to his idol through a various ways. For example, by following the fan meet, posting something on the Internet, and others. They also always want to collect things related to his idol, such as merchandise that display his favorite band or a guitar pick used during the concert of his favorite guitarists. 
Teens as a fans are also make a group and some even joined in the forum or a community that love a certain idol. In this community they intertwined relationships and actively share information. Furthermore, it appears also in daily lifebehavior. According to research conducted by Astuti (2012), which takes the object of teenage girls who are K-Pop fans, they have tendency to opt out the luggage and accessories used by the idol she likes and buy and collect albums of songs or films of their idol.

\section{RESEARCH METHOD}

The approach used in this study is a qualitative approach. Qualitative research seeks to uncover the uniqueness contained in individual, group, community, or organization in the daily life of a thorough, detailed, profound and justified scientifically (Miles \& Huber man; 1994: 6-7). Qualitative research is also an approach to research that reveals certain social situations to describe reality correctly, formed by the words based on the technique of collecting the relevant data obtained from the natural situation. In this study, researchers sought to express the uniqueness of the individual, in this case the teenage daughter of the initial level fan of boy band One Direction by elaborating speech, writing and behavior in the context of their par a social interaction with boy band One Direction and what things are behind them just like Bogdan and Taylor presented about qualitative approach (Sudikin, 2002: 2).

This research is a descriptive study that aims to describe the nature of a temporary nature happened at the time of the study, and examine the causes of a particular symptom (Consuelo G. Servilla.1993: 71). The nature of research related to the research objectives. The population used in this study is a collection of young women beginning level who is a fan of the boy band One Direction. In addition to population, also known as observation unit. Observation units used to select populations that can represent and in accordance by predetermined criteria researchers. Observation units used in this study is fan of One Direction who meet the established criteria.

Those criteria are female adolescents aged 11-15 years, are students who are an Indonesian and live in Jakarta and Yogyakarta. The selection is done by considering the fans of One Direction are mostly female adolescents. Reasons the researchers chose teenagers students is because almost all One Direction fans are usually teenager and a student. The reasons for selecting the place in Jakarta and Yogyakarta is to see a comparison between the behavior of adolescents who live in Jakarta and Yogyakarta on this matter.

Other specified criteria are they ever watch One Direction concert that held in Indonesia, buy official goods of One Direction (album and merchandise), quite active in social networks related to One Direction and a member of the One Direction fans club. The choosing of the observation units are because the purpose of this research is to know their background on how they come to like One Direction and how they saw the figure of his idol.

Participants or informants included in this study were selected using purposeful sampling techniques and criterion sampling strategies with criteria previously mentioned. When finding difficulty in determining the sources, researchers used snowball sampling technique considering the informant of this study has specific characteristics (Hennink, 2011: 100). This technique is done by asking the key informants about who can be the next respondents (Patton, 2002: 237).

The method used in this research is in-depth interviews as its primary data collection. We aimed to explore the views or opinions of resources on a specific topic by using semi-structured interview guide on topic of questions about how the interaction on parasocial relationship of girls to her idol, One Direction. How these teenagers find that One Direction that she continuously consumes on mass media, especially television and the Internet became part of her life. 


\section{Findings and Analysis}

\section{One Direction Boy Band Profile}

One Direction (shortened 1D) is a male pop vocal group from British-Irish that formed in London in 2010. This group consists of Niall Horan, Liam Payne, Harry Styles, Louis Tomlinson, and previously, Zayn Malik until March 25, 2015. Vocal group signed a contract with the record label owned by Simon Cowell, Syco Records, after becoming the third champion in the event of British singing competition, The X Factor in 2010. Encouraged by the international success in social media, four albums One Direction, Up All Night(2011), Take Me Home (2012), Midnight Memories (2013), and Four (2014) sints on the top of world music chart and make hits singles such as "What Makes You Beautiful", "Live While We're Young", and "Story of My Life". Their fifth studio single, "Made in the A.M.", was released on November 2015 ${ }^{1}$. Their achievements including five Brit Awards, four MTV Video Music Awards, eleven MTV Europe Music Awards, and 19 Teen Choice Awards from 19 nominations, as well as numerous other awards. According to Nick Gatfield, chief executive of Sony Music Entertainment UK, One Direction business field worth \$ 50 million in 2012. They were named as "Best New Artist" in 2012 by Billboard².

\section{- Informant Profile and New Media User}

In this study, the researchers conducted interviews to five informants. However, throughout the research process, only three people who could be considered to meet all the criteria of the research. They who considered as the most significant, their transcript of the interview was proceeded to the analysis process and processed into data findings. The three are JJ, GD, and VS.

In general, there are some similarities of the two informants, both are women who were on early adolescents (age range 11-15 years), living in the area used as a study region (Yogyakarta) and have interests and passions on One Direction. The third informant also students, which is in junior high school and are still depends on her parent, even though they all do not live with their parents or other family members.

\section{- New Media Usage}

From the findings of in-depth interviews with informants, can be explained that the informant is the viewers or audience of the spectacle and the latest news about their idol. In addition, they are also an active media audience because they can determine and assess their own different messages that loaded the media to fulfill the purpose of communication (Wang, Fink \& Cai, 2008 in West \& Turner, 2010 page 393). For example, as three informants in this study, GD, JJ and VS who find out the newest update of their idol in a variety of social media. Nevertheless, there is a difference from three informants. GD and JJ tends to prefer a IG accounts of a fandom because they think the fan-made accounts are often get more updates than the official social media accounts of One Direction (or which they often refer to as 1D). While VS prefer to follow the official social media accounts belongs to One Direction, especially their Instagram account.

The frequency and activity of media use by informants stated that they conform with social context as the research results by Perse \& Rubin (1990). In the findings of this study, it was found that the informants adjust the media consumption behavior of $1 \mathrm{D}$ with social context. For example, JJ when the school conditions were pretty relaxed, so that she could access information about 1D freely. Additionally, she can only access it through mobile phones at weekends. The same with GD, even though she was determined to hold the phone all day, she still adjust it to the environmental conditions. 
Adjustment is also evident in the third informant, VS. In daily life, she admitted that she was very active on Instagram. However, to fit in with friends who have diverse interests, she then decided to have two Instagram accounts; one Instagram account to be opened freely to her school friends, while the other specialized Instagram account she used to be able to access and upload any information about her idol, especially One Direction.

Elements such as mobility and loneliness are also important, for example, low mobility and high loneliness produce ritualized orientation and large dependence on media (Perse \& Rubin, 1990; AM Rubin \& Rubin, 1982a in Bryman \& Zilman, 2002 page 535). However, in this study researchers also observed the background and conditions experienced by the informants that these conditions support the consumption of media about 1D in their everyday. One of them is because they live far from their parents and families, informants spend more time in school and academic, so that loneliness is certainly inevitable. Thus, one of the things that support the parasocialritual behavior is that the low daily mobility of the informants (given that some of them had to stay in a dorm) and loneliness they experience.

\section{- Parasocial Interaction Dimension of the Informant}

Table 1

\begin{tabular}{|c|c|c|c|}
\hline $\begin{array}{c}\text { Para social Interaction } \\
\text { Dimension }\end{array}$ & Informant 1 (GD) & Informant $2(\mathrm{JJ})$ & Informant 3 (VS) \\
\hline Pseudo-friendship & $\begin{array}{l}\text { One Direction regard as a } \\
\text { boyfriend that is like a } \\
\text { friend }\end{array}$ & $\begin{array}{l}\text { Regarding OneD as } \\
\text { 'Oppa' (brother in } \\
\text { Korean Language) then } \\
\text { Zayn as a boyfriend/ } \\
\text { beloved husband. }\end{array}$ & $\begin{array}{l}\text { Regarding OneD as a } \\
\text { brother }\end{array}$ \\
\hline $\begin{array}{l}\text { Finding Friends (Social } \\
\text { Interaction) }\end{array}$ & $\begin{array}{l}\text { Following One Direction } \\
\text { Fandom on social media }\end{array}$ & $\begin{array}{l}\text { At first joining Line and } \\
\text { fan base but not stay for } \\
\text { long. }\end{array}$ & $\begin{array}{l}\text { Not overly follow OneD } \\
\text { fandom. Create a fan group } \\
\text { that contains her own } \\
\text { friends. }\end{array}$ \\
\hline $\begin{array}{l}\text { Sense of } \\
\text { comapanionship }\end{array}$ & $\begin{array}{l}\text { Feeling sad to hear one } \\
\text { member of One Direction } \\
\text { are out. Feel to know One } \\
\text { Direction and like them } \\
\text { more }\end{array}$ & $\begin{array}{l}\text { feel so lost when Zayn } \\
\text { out of oneD. She felt the } \\
\text { disappointment when she } \\
\text { saw the news and } \\
\text { developments in Zayn's } \\
\text { appearance since he was } \\
\text { the sole Muslim member } \\
\text { on oneD (according to } \\
\text { her become sloppy). She } \\
\text { even cried when } \\
\text { knowing the news that } \\
\text { Zayn were out of One } \\
\text { Direction. Although } \\
\text { comforted by his mother, } \\
\text { JJ still feel lost and sad. }\end{array}$ & $\begin{array}{l}\text { Feeling sad because there } \\
\text { are members of One } \\
\text { Direction that were out, } \\
\text { when she had just become a } \\
\text { fan of One Direction since } \\
\text { their concert in Indonesia. } \\
\text { Knowing that One Direction } \\
\text { disband only temporarily. } \\
\text { wept when she saw video } \\
\text { clips with Zayn still in it }\end{array}$ \\
\hline Performer Competency & $\begin{array}{l}\text { Liked One Direction } \\
\text { because they are unique } \\
\text { and different from the } \\
\text { others. Believing that One } \\
\text { Direction (with integrity in } \\
\text { the commitment) is not } \\
\text { disbanded completely. One } \\
\text { Direction is irreplaceable } \\
\text { because of its uniqueness. } \\
\text { Liked Louis and Harry as a } \\
\text { favorite member because } \\
\text { Louis always wins in the }\end{array}$ & $\begin{array}{l}\text { physical beauty, then } \\
\text { followed by their } \\
\text { behavior that according } \\
\text { to her was funny. In } \\
\text { addition, the values of } \\
\text { good behavior from the } \\
\text { members of One } \\
\text { Direction also be a plus } \\
\text { in the eyes of JJ. In terms } \\
\text { of singing and dancing } \\
\text { skills, she said oned } \\
\text { unique and not }\end{array}$ & $\begin{array}{l}\text { Loving Niall Horan as } \\
\text { favorite member because he } \\
\text { plays guitar nicely and } \\
\text { handsome }\end{array}$ \\
\hline
\end{tabular}


Early Adolescent Behavior on Media Toward Idol Figure

(Parasocial Study on Preliminary Youth as an Effect of New Media)

\begin{tabular}{|c|c|c|c|}
\hline & $\begin{array}{l}\text { group debate, and harry } \\
\text { has beautiful long hair. }\end{array}$ & $\begin{array}{l}\text { exaggerated. In addition, } \\
\text { their language are easy to } \\
\text { be understood and it is a } \\
\text { plus values that made her } \\
\text { loved oneD }\end{array}$ & \\
\hline Relationship Reality & $\begin{array}{l}\text { Buy the album and } \\
\text { merchandise from One } \\
\text { Direction by saving } \\
\text { money. } \\
\text { Follow all One Direction } \\
\text { activities through social } \\
\text { media and the internet }\end{array}$ & $\begin{array}{l}\text { Buy the album, poster } \\
\text { and merchandising of } \\
\text { Zayn and Nail. And it } \\
\text { bought by her mother. }\end{array}$ & $\begin{array}{l}\text { Buying One Direction } \\
\text { perfume. Saving millions of } \\
\text { rupiah to buy it (with the } \\
\text { permission of his mother) }\end{array}$ \\
\hline Guidelines in behavior & - & $\begin{array}{l}\text { Idolized Niall that not } \\
\text { have tattoo and careless, } \\
\text { and rejecting free sex }\end{array}$ & $\begin{array}{l}\text { Oned, particularly Niall, not } \\
\text { just experts in singing but } \\
\text { also in playing music }\end{array}$ \\
\hline Personal identity & - & - & - \\
\hline Pathologic Audience & - & $\begin{array}{l}\text { Lying and skipped } \\
\text { school along with her } \\
\text { friends to watch oneD } \\
\text { concert. She also buy } \\
\text { tickets from scalpers to } \\
\text { be able to watch the } \\
\text { concert. }\end{array}$ & - \\
\hline
\end{tabular}

For the first dimension of interaction parasocial; Pseudo friendship GD called the One Direction's members as her boyfriend and close as a friend. While JJ see One Direction as her "oppa" (big brother for men in Korean language) and Zayn as their boyfriend / husband. However, to show their affection, they willingly see him (Zayn Malik) dating someone else, rather than seeing their idolbeing suspected homosexuals. they also felt that Zayn was the closest friend of them so they willingly defend it tooth and nail if there are people or friends mock their idol.

Unlike the two previous informants, VS regard One Directions' members more as a brother. She felt that the idol created the work for her alone so that she feels a special relationship among them, like a distant relative who, though far apart still feels close to the heart. The feeling of close relationship makes VS feel that their songs could even relieve her emotions, as if they understand VS' feeling. From these finding it can be said that there are parasosial interaction behaviors within three informants. Parasosial interaction is the interaction that occurs when people interact with those presented by the media as if these people are real. Thus, the interaction parasosial is an illusion of the relationship between the audience with the performers, which is customly made by media agenda. In short, interaction parasosial explain the one-sided relationship that show how a person knows a lot about other people, but other people do not know about that person, so the relationship is not reciprocal (Horton and Wohl 1956; Perse and Powell 1985).

It can thus be seen from the three informants. Obviously, there is only one-sided relationship can be perceived by the informants. On one side of the three informants know much about the 1D, on the other side, the idol can not allow to get into their lives easily. The results, only relationships apparent that exists between fans (the informants) with One Direction as their idol.

For the second dimension of interaction parasosial; social interaction in making friend, in this context, the informants get the functionality of social interaction both of friendship in the real world as well as friends in cyberspace (through the fan base fandom official, as well as a network of friends in the real world). Regarding the cyber networks, GD use fan base in not only to make friends, but also as a source of the latest information about One Direction. 
While JJ at first initially liked One Direction is not influenced by friendship of her peergroup friends, she who had incorporated into One diretion fanbase, then stepped down from the network because she thinks the communication is not fun anymore. Therefore, she prefers being a fan that does not belong to any fandom. However, she remains open when meeting with fellow fans of One Direction's fans, such as when she meets other fans at OneDirections concert or at fans gathering event. Unlike the GD and JJ who tend to be more able to open to friendship of One Direction's fans (both in the real world or fandom new friend fellow enthusiasts of One Direction), VS prefer to form her own group of OneDirections' enthusiasts consisting her closest friends only. She does not really like to follow updated informations that published on in the One Direction fandom's sites.

The third dimension; empathetic to the performer as a sense of companionship. The informants felt deep feelings of empathy to their idol. In addition, the informants also feel an emotion or a feeling of close relationship as if they have a special relationship with the idol. For GD, it is shown when she feels sad when she discovered one of the members of One Direction (Zayn) out from the group. Nevertheless, she feels familiar with One Direction and like them more. Similar as GD, JJ also feels very sad when Zaym out of One Direction. She disappointed when she saw the news and updates of Zayn appearance since that only member of One Direction who are Muslims has changed (in a bad way). She even cried when knowing the news that Zayn out of One Direction. Although she had comforted by her mother, JJ still feels so disapointed and sad. As with JJ and GD, VS also feel sad when they get the news. In fact, if we look at the period time, VS know One Direction just in short time (since their first concert in Indonesia). She also hopes Zayn could reunite with One Direction as his first place for developing his career. Besides in factshe could not accept the reasons of Zayn being out from One Direction, she believes that Zayn just out for a while, and he will rejoin One Direction again in the future. She showing it by crying every time she looks back on their previous music video of One Direction when Zay still joined to the group.

Next dimension is competence of performers, which is the dimension that explains the competences of the idol that give motivation or reason for informants to love One Direction. GD explain that they are unique and different from the other idol that exist. By believing that One Direction ( have an integrity in their commitment) is not disband completely. One Direction is irreplaceable because of its uniqueness. They like Louis and Harry as their favorite member for Louis always wins in the group debate (have a great communication skill), and Harry has beautiful long hair (physically beautiful).

In contrast to GD, JJ likes One Direction firstly because of his physical beauty, then followed by their funny behavior. In addition, she values more of good behavior from the members of One Direction. In terms of singing and dancing skills, she thinks One Direction unique and not excessive. In addition, the use of the language of instruction that is easily understood to be one of the more distinct values that make she love One Direction. As for VS, characteristic and uniqueness OneDirection that make her like British group. According to her, it the variation of their voices characteristic as they sang or performed together could produce a remarkable harmonization. In addition, the ability of the personnel that not only have good singing skill but also able to play music instruments is the reason VS likes them, especially Niall Horan.

Through these findings it was found that the three informants experienced parasosial relationship and it appears from the interaction parasosial they do. Parasosial interaction also is a sense of friendship with the persona in the media that makes the audience feel emotionally close to the personality of the media as an experience that is perceived as "the 
search for guidance from persona media, search personalities media as a friend, supposes to be part of the social world of their favorite programs and intends to meetirwith that performer(s) ". Audiences often see media persona specially in a parallel action as their interpersona friend-as a natural thing, or as an attractive ordinary people. It is the format and technique of media programme that boost parasosial relationship. (Rubin, 1985 pages 156-157 in Brymant and Zilman, 2002 page 540). From the findings of this study it can be said that the informants are emotionally feel close relationship that made the emergence of a delusive experience of relationship with their idol as close friends in the real world. How media to 'package' the members of One Direction is also a major contribution of this adolescent informants feel toward a close relationship with the idol.

In the next dimension, that reality of relationship, the informant perpetuates the pseudo- friendship that exists between them and the idol through efforts they do, such as purchase items related to her idol, whether in the form of a music album videos, books, magazines, posters, until other merchandise. For GD and JJ, this is one of the actions required to be taken by the fans of One Direction. For the example GD saving his pocket money to be able to buy the album and merchandise of One Direction and although she could not watch One Direction concert in Jakarta she watching the video on the Internet and follow all activities of One Direction through social media and the internet.

Contrast to GD who bought the album by saving, JJ get a poster and merchandising of Zayn and Niall with her mother bought for her. If JJ bought One Direction merchandise with her own money and GD get it from her mother, VS is more interested in buying perfume that officially launched by One Direction. Of course, after obtaining the approval from her mother. To acquire it too, VS should save money for a few months without the help of her mother. She said that she felt a sense of closeness and love to wear the perfume of One Direction.

Acting on the dimensions of The code guidelines, ie the values of good behavior that are imitated by the informant from the idol, it was found that JJ idolized Naill because of his behavior that do not following his friends on tattooing their bodies and keeping his virginity until hegot married. In contrast with it, as described earlier, for VS, Niall guitar skill makes VS practice guitar more. While GD did not find any good values as a guideline that she imitates.

As well as the Personal Identity dimension, they do not create or display a certain identity that makes them specifically looked like a fan of One Direction. Lastly, there is an Audience Pathological dimension, GD who showed no par a social behavior on interaction did not mention of anything related to it. While $\mathrm{JJ}$ had to make the moment One Direction concert as a moment to lied together with her school friends who both like One Direction and want to come watch their concert in Jakarta.

Associated with the use of new media, the research of uses and gratification media carried by Klapper and also Cowles in this case focuses on motivation and the consumption of audience to see what people do with media (Klapper, 1963 in Bryman and Zilman, 2002, page 529; Cowles ( 1989) and found that interactive media (eg, media and social networking on the Internet) is considered to have more personal characteristics of media than non-interactive. this is also reinforced by the findings in this study, that the interactive media such as the Internet and social media in it, to facilitate the needs of the One Direction fans, especially young women who become informants in this study.

Interactivity between fan and artist One Direction is indeed echoed as a One Direction's success on career achievement globally. Bill Werde, a representative of Billboard magazine commented on One Direction's success in the United States, namely: 
"There's a lot of possibility here, there's a lot of upside ... that level of talent with those kinds of looks...it's really a perfect storm for a massive, massive successful phenomenon. ${ }^{1}$

Meanwhile, Sonny Takhar, director of Syco Records argued about the role of social media that now has become the new radio. One Direction and fans are using social media and this helps create the illusion that they could be closer to their fans. Until December 2015, recorded that One Direction Twitter account has collected more than 26 million followers, more than 204 million viewers on YouTube and 4 million enthusiasts on Face book.

\section{CONCLUSIONS}

The conclusion of this study is the informants as the active audience of their idol's performances because they can determine and assess their own different types of media and messages to fulfill their desires of the idols presents on parasocial interaction communication.

In terms of behavior on media consumption frequency, they adjust it to their social contextual that led to the interaction parasosial. Mobility and loneliness experienced by the informants are also important, such as low mobility and high loneliness produces high ritualized orientation on media consumption and dependence on media It led to the routine interaction parasosial behavior of informants.

Parasosial interaction behavior were found on informants in this study are: pseudofriendship which makes the informant seems to have a close relationship with his idol; social interaction (in making friends) that makes the informants participated in a network of friends of One Direction fans both in the real world or in cyberspace; empathy for the performers (as a sense of companionship) that emotional feeling which make informants feel have strong relationship with the idol; the competence of the performer that is a positive assessment by the informants as the motivation or the reason they love their idols; the reality of the relationship that they do a real effort to perpetuate their feelings and parasosial relationship between them as a fan with his idol; Code of Conduct which makes the informants imitate behavior of their idol 1; as well as the audience pathological tendency to do bad things that are intentionally done to achieve their needs of their idols.

\section{SUGGESTION}

This study suggests that tendency of parasosial behavior particularly need to be concerned by everyone, especially families, because in certain conditions, it may develop and refer to pathological behavior that is not only detrimental to the individual fan itself, but also the surroundings socially. Moreover, the tendency to become ardent fans would not only have an impact on behavior in social interaction, but also have an impact on the mental and psychological condition. Related to psychologicallyof adolescents who still have unstable character, thus need a special attention to prevent adverse psychological condition in the future.

Academically, this research is limited to the selectivity of media consumption on the use of new media that is not particularly specific. For further researchs we suggested assess in the specific social media. Moreover, in terms of methodology, considering the uses and gratification theory in this new media, in particularly; the interaction parasosial, is a continuation of the development of a theory that originated from the positivistic paradigm, the researchers in this study suggest to use research using mixed methods approach to examine more comprehensively on similar studies in the future.

\footnotetext{
${ }^{1}$ http://www.theguardian.com/music/2012/mar/15/one-direction-fab-five-america 
Early Adolescent Behavior on Media Toward Idol Figure

\section{REFERENCES}

1. Ali, Muhammad dan Asrori. (2009). Psikologi Remaja Perkembangan Peserta Didik. Jakarta: Bumi Aksara.

2. Balai Pustaka. (1994). Kamus Besar Bahasa Indonesia. Jakarta: Balai Pustaka.

3. D. Gilles. (2000). Illusions of immortality. A psychology of fame and celebrity. London: MacMillan.

4. Hennink, Monnique, Inge Hutter, Ajay Bailey. (2011). Qualitative Research Methods. London: Sage.

5. Horton, D\& Wohl, R. (1956). Mass communication and para-social interaction: observation on intimacy at a Distance. Psychiatry.

6. Jenkins, Henry. (2003). Rethinking Media Change: The Aesthetics of Transition. Media in transition. Cambridge, Mass.: MIT Press.

7. Maltby, J., Houran, J., Ashe, D., \& McCutcheon, L. E. (2001). The Self-Reported Psychological Well-Being of Celebrity Worshippers. North American Journal of Psychology.

8. McQuail, Denis. (2010). Mass Communication Theory, 6th Edition. London: Sage Publication.

9. Miles, Matthew B \&A. Michael Huberman. (1994). Qualitative Data Analysis: An Expanded Sourcebook. London : Sage.

10. McLuhan, M. (1964). Understanding Media: The Extensions of Man. McGraw-Hill.

11. Patton, Michael Quinn. (2002). Qualitative Research \& Evaluation Methods. London: Sage.

12. Poerwandari, E. K. (2001). Pendekatan kualitatif untuk penelitian perilaku manusia. Jakarta: Lembaga Pengembangan Sarana Pengukuran dan Pendidikan Psikologi (LPSP3) Universitas Indonesia.

13. Rakhmat, Jalaluddin. (2001). Psikologi Komunikasi. Bandung: PT Remaja Rosdakarya.

14. Sarwono, Sarlito Wirawan. (2006). Psikologi Remaja. Jakarta: Raja Grafindo.

15. Smet, B. (1994). Psikologi Kesehatan. Jakarta: PT Gramedia.

16. Taryadi, Alfons. (1999). Buku dalam Indonesia Baru. Yayasan Obor Indonesia.

17. Nadia, I. (2001). Interaksi Parasosial Terhadap Oprah Winfrey dalam The Oprah Winfrey Show: Studi Khalayak Mahasiswi Universitas Indonesia. Depok: FISIP UI.

18. Mahayani, Novi. (2007). Hubungan Antara Konsep Diri Dengan Komunikasi Interpersonal Pada Remaja. Yogyakarta: Fakultas Psikologi dan Ilmu Sosial Budaya UII Yogyakarta.

19. O'Brien, Jon. (2015). One Direction's Biography. 7 Desember 2015. http://www.allmusic.com/artist/one-direction$\underline{\text { mn0002766592/biography }}$

20. Hampp, Andrew. (2012). One Direction: Q\&As with Billboard's Top New Artist of 2012. 7 Desember 2015. http://www.billboard.com/articles/news/1481395/one-direction-qas-with-billboards-top-new-artist-of-2012

21. Sugarscape. (2013). The Sunday Times Rich List 2013 - One Direction Zoom Into Under 30s, Paul Mccartney Remains Loaded. 7 Desember 2015. http://www.sugarscape.com/celebs/news/a851889/the-sunday-times-rich-list-2013-one-direction-zoom-intounder-30s-paul-mccartney-remains-loaded/

22. Berg, Madeline. (2015). One Direction's Earnings: $\$ 130$ Million in 2015.7 Desember 2015. http://www.forbes.com/sites/alfredkonuwa/2015/12/14/roman-reigns-won-over-fans-before-winning-wwe-championship/

23. Caulfield, Keith. (2014). One Direction's 'Four' Makes Historic No. 1 Debut on Billboard 200 Chart. 7 Desember 2015. 
http://www.billboard.com/articles/columns/chart-beat/6327789/one-direction-four-no-1-debut-billboard-200

24. BBC. (2014). One Direction top 2013 global album chart. 7 Desember 2015. http://www.bbc.com/news/entertainment-arts$\underline{28599903}$

25. Joshi, Priya. (2015). One Direction to 'disband' in March to pursue solo projects. 7 Desember 2015. https://uk.news.yahoo.com/one-direction-disband-march-pursue-212342030.html\#EgRT6Vb

26. The Guardian. (2014). One Direction: the Fab Five Take America. 7 Desember 2015 http://www.theguardian.com/music/2012/mar/15/one-direction-fab-five-america 